\title{
Schizocordulia gen. nov. related to Aeschnosom Selys with description of the female and additional data on the male of Schizocordulia rustica (Selys) comb. nov. (Odonata, Corduliidae)
}

\author{
Angelo B.M. Machado \\ Departamento de Zoologia, Instituto de Ciências Biológicas, Universidade Federal de Minas Gerais. Caixa Postal 486, \\ 31270-901 Belo Horizonte, Minas Gerais, Brasil.
}

\begin{abstract}
The monotypical genus Schizocordulia is created for Schizocordulia rustica (Selys, 1871) comb. nov. known from a single male from Bahia, Brazil lacking the anal appendages. The female is described and the redescription of the male made by GeIJKEs (1970) is completed by the description and illustration of the penis, the anal appendages and the pilose plate. The main characters separating the new genus from the closely related Aeschnosoma Selys, 1870 are the bifid male inferior appendage, the very long internal branch of the hamulus, the presence of a pilose plate on the male $7^{\text {th }}$ abdominal segment, and the large and complex valvula vulvae of the female. The study was based on 33 males and 2 females, which allowed an evaluation of the intraspecific variations in Schizocordulia rustica.
\end{abstract}

KEY WORDS. Brazil, behavior, ecology, taxonomy.

RESUMO. Schizocordulia gen. nov. relacionado a Aeschnosoma Selys com descrição da fêmea e dados adicionais sobre o macho de Schizocordulia rustica (Selys) comb. nov. (Odonata, Corduliidae). Cria-se o gênero monotípico Schizocordulia para Schizocordulia rustica (Selys, 1871) comb. nov. espécie conhecida de um único exemplar macho sem os apêndices anais. Descreve-se a fêmea e a redescrição do macho feita por GeljkEs (1970) é completada pela descrição e ilustração do pênis, da placa pilosa e dos apêndices anais. Os principais caracteres utilizados para separar Schizocordulia do gênero afim Aeschnosoma Selys, 1870 são o apêndice inferior do macho bífido, o ramo interno do hâmulo muito longo, a presença de uma placa pilosa no $7^{\circ}$ segmento abdominal e a válvula da vulva da fêmea grande e complexa. Este estudo foi baseado em 33 machos e 2 fêmeas, o que permitiu uma avaliação das variações intraespecíficas em Schizocordulia rustica.

PALAVRAS CHAVE. Brasil, comportamento, ecologia, taxonomia.

SELYs (1871) described Aeschnosoma rustica based on a single male from Bahia, Brazil. The specimen was figured by MARTIN (1906) whose illustrations, as pointed out by GEIJKEs (1970), are very inaccurate. In his key for the species of Aeschnosoma, Cowley (1934) followed the descriptions of Selys (1871) and Martin (1906). Finally GeIJKes (1970), based on the examination of the holotype from the Museum of Berlin, made a good redescription and illustrations of the specimen. However, he could not describe the anal appendages that were lacking from the holotype and did not illustrate the penis. Thanks to the good help of Prof. Olaf H.H. Mielke we received 33 males and three females of $A$. rustica from Paraná State, Brazil. The new material allowed us to complete the redescription made by GEIJKES (1970), to study the intraspecific variations mainly of the venation and also to describe the, so far, unknown female of the species. These studies revealed some characters not shared by the other species of Aeschnosoma and led us to establish herein the monotypical genus Schizocordulia for Aeschnosoma rustica Selys, 1871.

\section{Schizocordulia gen. nov.}

Generotype. Aeschnosoma rustica Selys, 1871.

Etymology. From the Greek schizo that means to split, a reference to the fact that the inferior appendage of the male is split in two branches.

Diagnosis. Brown cordulids of small size, with some metallic bluish green reflection on the pterothorax. In fore wings 1 accessory bridge crossvein (80\%) in hind wings none (100\%). In forewings nodus in the distal half of the wing length. Triangles with three cells (100\%) in fore wings and two cells (100\%) in hind wings. Proximal side of triangle in hind wings coinciding with arculus or very slightly distal from it. Subtriangles in fore wings 3-celled (100\%). In fore wings two rows of cells between $\mathrm{R}_{2}$ and $\mathrm{R}_{3}$ starting under the pterostigma; in hind wings starting slightly distal from midway between the nodus and the pterostigma. Cubito-anal crossveins in fore wings 3 (90\%), in hind wings $2(100 \%)$. Discoidal field in fore wings starting 
with three cells against triangle followed by two rows for a distance of 2-4 cells, and again three rows followed by an increasing number of cells until 8-10 at the enlarged wing margin. Anal loop elongated extending to about the level of the fork of Rs, with 15-17 cells. Anal triangle with two cells. Anal field in hind wings of the male with three rows of cells for a distance of 2-5 cells followed by two rows for a distance of 3-6 cells. In the females with three rows for a distance of one cell followed by two rows to the end. Membranule of the male with the free margin straight ending distal to the apex of the anal triangle. Eye seam large (1,1-1,2 mm). Abdomen dilated on segment 7-8. Ventral tergal part of 7 with a pilose plate (Fig. 1). Penis short, without cornua (Fig. 2). Hamulus with an extremely high and rounded inner branch, with a brush of long hairs on the top (Fig. 3). Genital lobe minute, distal third of inferior appendage bifid (Fig. 4). Female valvula vulvae (Fig. 4) large, formed by two tapering subtriangular processes.

\section{The affinities and characters of Schizocordulia}

Traditionally the definition of the genera in Corduliidae has been made using rather venational than structural characters. However, for establishing the genus Navicordulia (Machado $\&$ Costa, 1995) structural characters where more important than venational and allowed a clear separation from the closer genus Dorocordulia Nedham, 1901 (MACHADo \& Costa 1995). Also for the establishment of Schizocordulia, the structural characters proved to be more important than venational. The closer genus to Schizocordulia is Aeschnosoma and the characters separating these two genera are shown in table I.

The taxonomic significance of some of these characters deserves further consideration as follows:

a) Inferior appendage bifid (Fig. 4). As far as I know, this character is unique, in neotropical Corduliidae whose inferior appendages have the usual triangular form. In Gomphomacromia Brauer, 1964, however, the inferior appendage is quadrangular with two distal processes, one on each side.

b) Extremely long inner branch of the hamulus (Fig. 3): This is also an unique character among neotropical Corduliidae.

c) Pilose plate on segment 7 (Fig. 1). The specialized pilose structures of neotropical Corduliidae have been studied by Machado \& Costa (1995). They usually occur on segment 8 rather than on 7 as in Schizocordulia and Navicordulia. The pilose plate of Schizocordulia is formed by a ventro-medial expansion of the distal part of the ventral carina that becomes thicker and is medially provided with stiff hairs (Fig. 1). It corresponds to the lateral parts of the pilose complex of Navicordulia (MACHADo \& CosTA 1995) but in Schizocordulia the expansion of the lateral carina is larger and the hairs are directed medially not distally and medially as in Navicordulia. Thus this specialized pilose area of Schizocordulia, now denominated pilose plate, by its position and structure is unique among neotropical Corduliidae.

d) Complex valvula vulvae (Figs 7-9). The valvula vulvae of $S$. rustica appears as two tapering subtriangular processes reach- ing distally to $1 / 3$ of the length of sternite 9 (Fig. 7). It is completely different from the valvula vulvae of the Aeschnosoma species.

\section{Schizocordulia rustica (Selys, 1871) comb. nov.}

\section{Additional data on the male}

The male anal appendages of $S$. rustica that are lacking in the holotype described by Selys (1871) and Geijkes (1970) are herein described. The variations of the venation and size of the species based in 20 specimens is also studied

Superior anal appendages (Figs 5 and 6) black, as long as segments 9-10, in lateral view as in figure 6; in dorsal view (Fig. 5) slightly convergent on the basal two thirds and strongly divergent on the distal third. Inferior appendage (Figs 4 and 6) black with the basal two thirds broad, the distal third bifid, the two branches strongly divergent (Fig. 4), ending in a fine tip (Fig. 6).

Venation. Wings hyaline slightly suffused with yellow in the anal area, the yellow in some species extending to large areas of fore and hind wings. Antenodals in fore wings (FW) 10 (60\%), 11 (30\%), 12 (10\%); in hind wings (HW) 6 (20\%), 7 (20\%), 8 (50\%), 9 (10\%). Postnodal in FW 4 (30\%), 5 (60\%), 6 (10\%); in HW 6 (20\%), 7 (20\%), 8 (50\%), 9 (10\%). Substigmal crossveins in FW 1 (80\%), 2 (10\%), 3 (10\%); in HW 1 (90\%), 2 (10\%); postigmals in FW 2 (10\%), 3 (50\%), 4 (40\%), in HW 3 (90\%), 4 (10\%). Accessory bridge crossveins in FW 1 (80\%), 0 (20\%) in HW 1 (100\%); supratriangular crossveins in FW 2 (20\%), 3 (80\%), in HW 1 (100\%). Number of cells in triangle in FW 3 (100\%), in HW 2 (100\%), subtriangle in FW 3 (100\%), in HW 0 (100\%). Double rows of cells between R2-R3 in FW starting under the pterostigma (100\%) in HW starting slightly distal from midway between the nodus and the pterostigma with 2 (10\%), 3 (20\%), $4(50 \%)$ and $5(20 \%)$ rows of cells proximal to it in midway. Cubito-anal crossveins in FW 3 (90\%), or 4 (10\%) in HW 2 (100\%). One row of cells in Rspl and Mspl in both wings. Number of cells in Mspl in FW 5 (20\%), 6 (10\%), 7 (50\%), 8 (20\%), in HW 5 (20\%), 6 (30\%), 7 (50\%). Number of cells in Rspl in FW 6 (30\%), 7 (40\%), 8 (30\%) in HW 6 (10\%), 7 (10\%, 8 (70\%), 9 (10\%). Discoidal field in FW starting with three cells against triangle (100\%) followed by two rows of cells for a distance of 2 (30\%), $3(40 \%)$ or $4(30 \%)$ cells and then three rows of cells for a distance of 2 (30\%), 3 (40\%), 4 (30\%) and then an increasing number of cells until 8-10 cells at the margin; in HW with 2 (40\%) or $3(60 \%)$ cells against triangle followed by 2 (90\%) or 3 (10\%) rows of cells for a distance of $2(40 \%)$, or $3(60 \%)$ cells and then 3 rows for a distance of 4 (30\%), 5 (30\%), $6(30 \%)$ or 7 (10\%) cells and then an increasing number of cells until 8-10 at the margin. Anal loop long with the heel at the level of the middle fork of Rs with a total of 15 (20\%), 16 (30\%), and 17 (50\%) cells. One cell between the distal end of anal loop and the hind margin of the wing (100\%). Anal field in HW with three rows of cells for a distance of $2(20 \%), 3(50 \%), 4(10 \%)$, or 5 (20\%) cells followed by three rows for a distance of $3(20 \%), 4$ $(10 \%), 5(40 \%), 6(10 \%)$, or $7(10 \%)$, or $8(10 \%)$ cells. Anal tri-

Revista Brasileira de Zoologia 22 (3): 775-779, setembro 2005 


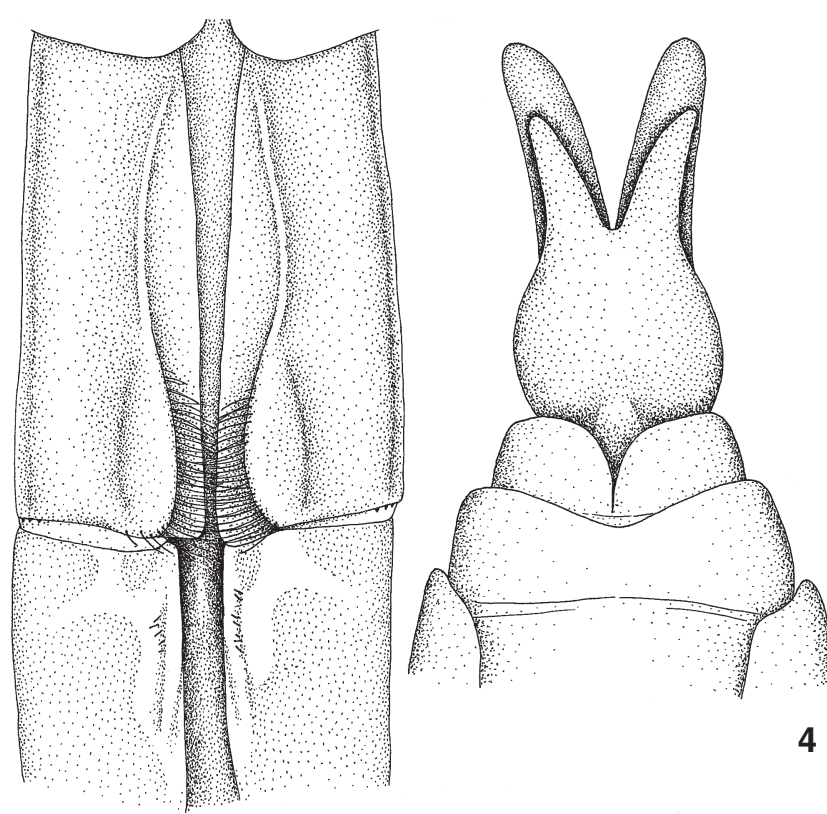

1

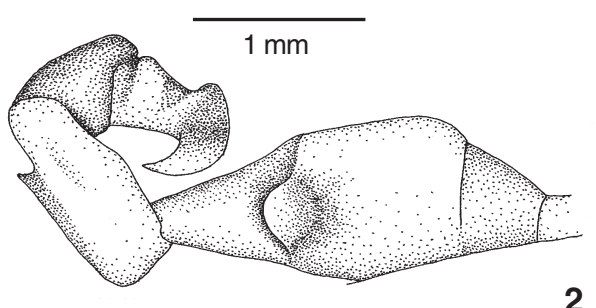

2

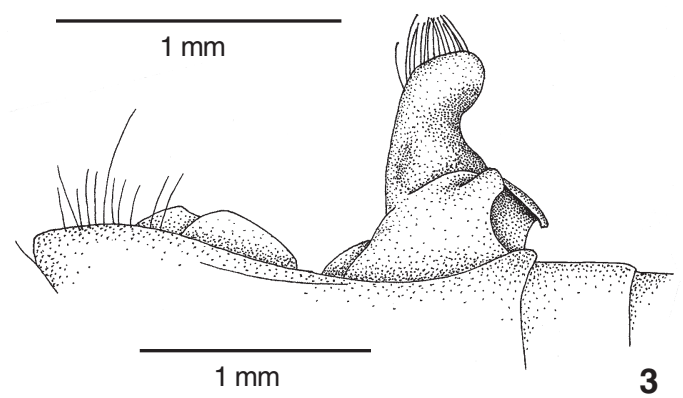

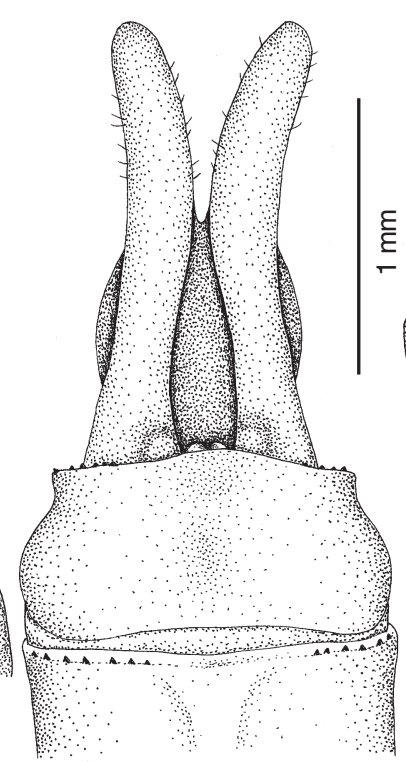

5

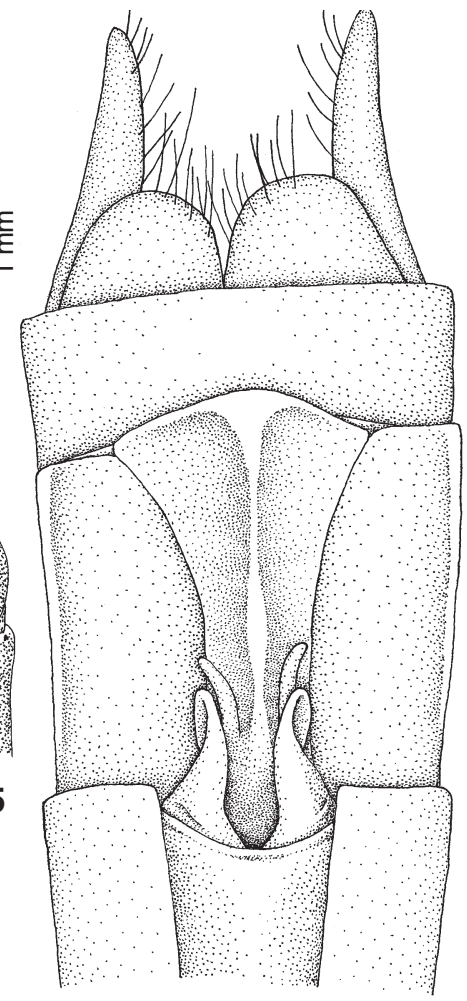

7

Figures 1-9. Schizocordulia rustica. (1-6) Male, showing the pilose plate of abdominal segment 7 (1), penis in lateral view (2), genitalia of $2^{\text {nd }}$ abdominal segment in lateral view (3), inferior anal appendage in ventral view (4), superior anal appendage in dorsal view (5) and lateral view (6); (7-9) female: ventral view of abdominal segments 8-10 (7) and sternite of abdominal segment 8 showing details of the valvula vulvae after removal of the tergum of segment 8 and the abdominal segments 9-10, in ventral (8) and oblique ventral (9) views.

angle with two cells (100\%). Membranule with the free margin straight, ending distally from the apex of the anal triangle.

Measurements (mm). total length 33,3-40,0, mean 37.6; abdomen without appendages 23.1-27.5, mean 25.0; superior appendages 1.9-2.5, mean 2.2; hind wings 25.3-29.4, mean 27.1; pterostigma 1.9-2.3, mean 2.0; hind femur 6.2-8.0, mean 6.9; eye seam length 1.1-1.2.

\section{Description of the female}

Head. Labium yellow, labrum yellowish brown. Anteclypeus, postclypeus and lateral part of frons olive brown. Remaining parts of frons and vertex brownish red. Occiput olive brown with a fringe of hairs at the back, almost continuous with similar fringe at the rear of the head behind the eyes.

Thorax. Prothorax light brown with the posteriror lobe 
Table I. Characters separating Schizocordulia from Aeschnosoma.

\begin{tabular}{|c|c|c|}
\hline Characters & Schizocordulia & Aeschnosoma* \\
\hline Male inferior appendage & With the distal third bifid (Fig. 4) & Triangular and not bifid \\
\hline Hamulus & $\begin{array}{l}\text { Inner branch extremely high having on top } \\
\text { a brush of long hairs (Fig. } 3 \text { ) }\end{array}$ & $\begin{array}{l}\text { Inner branch not high and without a brush of } \\
\text { hairs }\end{array}$ \\
\hline Genital lobe & Minute (Fig. 3) & Well developed \\
\hline $\begin{array}{l}\text { Distal part of ventral carina of male } \\
\text { abdomen segment } 7\end{array}$ & $\begin{array}{l}\text { Enlarged, dilated and medially provided } \\
\text { with stiff hairs (pilose plate) (Fig. 1) }\end{array}$ & Not dilated and without a pilose plate \\
\hline Valvula vulvae & $\begin{array}{l}\text { Large, formed by two tapering subtriangular } \\
\text { processes (Fig. 7) }\end{array}$ & $\begin{array}{l}\text { Small and not formed by two tapering } \\
\text { subtriangular processes }\end{array}$ \\
\hline Male membranule & $\begin{array}{l}\text { With the free margin straight and ending } \\
\text { distally to the apex of anal triangle }\end{array}$ & $\begin{array}{l}\text { With the free margin posteriorly curved ending } \\
\text { at the apex of the anal triangle }\end{array}$ \\
\hline Male hind wings length & $25.3-29.4$ & $33.0-43.0$ \\
\hline Male abdomen length & $23.1-27.5$ & $33.0-45.0$ \\
\hline
\end{tabular}

* Data obtained from the literature and from species in the author's collection (A. forcipula Selys, 1871, A. maritzae Santos, 1981 and $A$. auripennis Geijkes, 1970).

small and rounded. Pterothorax brown with metallic blue reflections more evident laterally and with three yellow stripes one at the mesepisternun adjacent to the humeral suture, another at the metepisternum and a third one at the metepimeron. Legs black with the under side of the fore and middle femorae brown. Inner side of hind femur with two rows of short triangular spines with the tips directed distally. Wings hyaline slightly suffused with yellow in the anal area. Veins black, pterostigma yellowish brown.

Venation. Similar to that of the male except for the anal field that has three rows of cells adjacent to the anal triangle followed by two rows throughout.

Abdomen. Segment 2-3 very dilated laterally and dorsoventrally. Segments 7-10 gradually increasing in width. Segments 12 yellowish, 3-7 dorsally yellow with a black distal ring, laterally black. Segment 8 black with a yellow latero-basal spot. Segment 9-10 dark brown. Appendages black, straight with tips bluntly rounded Valvula vulvae (Figs 7-9) in ventral view formed by two tapering subtriangular processes basely brown, distally black. They reach distally to $1 / 3$ of the length of sternite 9 (Fig. 7) almost touching the style. After removal of the tergites of segments 7-8 and abdominal segments 9-10 (Figs 8 and 9) it becomes clear that the two processes of the valvula vulvae are fixed through a base piece to the hind part of the sternite 8 (Fig. 8). In oblique view each processes has a rounded dorsal plate (Fig. 9). Subgenital plate strongly keeled hind margin straight reaching to the level of the base of segment 10 (Fig. 7).

Measurements ( $\mathrm{mm})$. Total length 38; abdomen without appendages 28.0; appendages 1.2; hind wings 26.9-27.2, mean 27.0; pterostigma 2.1; hind femur 5.9-6.3, mean 6.1; eye seam length 1.1

Material studied. BraziL, Paraná: Pontal do Paraná (Pontal do Sul, altitude 5 m). Males: 24-II-1996 (4); 2-I-97 (3); 9-II-1997 (3); 2-I-1999 (3); 15-I-2000 (10); 26-II-2001 (4); 03-I-2003 (3); 20-XI-2004 (2), 26-XII-2004 (1). Females: 15-I-2000 (1); 1-I-
2001(2). Total: 330 and 3 0, O. Mielke leg. Material deposited in the author's collection at Belo Horizonte, Minas Gerais.

\section{Taxonomic remarks}

A preliminary question that comes out is to what extent the identification of the Paraná specimens as A. rustica is correct knowing that the male holotype lacks the taxonomically important caudal appendages. For this identification the original description of Selys (1871) and mainly the redescription and illustrations of the holotype made by GeIJKes (1970) were used. The Paraná species agreed fairly well with the description of GeIjKes (1970) except for the following points: The face color is stated by GEIJKEs (1970) as being brown whereas in 90\% of the Paraná specimens the color is brownish red. However $10 \%$ of the specimens have the color as described by GeIJKES (1970). In his description GeIJKes (1970), in addition to the humeral and metepimeral yellow stripes mentions the presence of a mesepimeral stripe whereas our material shows a metepisternal stripe. SelYs (1871) mentions an humeral, a median and a terminal stripe. A median stripe is more compatible with a metepisternal than with mesepimeral one. It is therefore probable that the difference might be due to a mistake of GeIJKEs (1970). This author did not mention that the anal area of the holotype is suffused with yellow as shown by the specimens from Paraná. However Selys (1871) mentions that in the holotype the hind wings are "à peine laveé d'ochracé pale vers l'angle anal des inferiors". In the Parana specimens the distal third of the fore tibiae have a row of 8-9 modified spines situated very close together at the anteromedial part of the tibiae where they replace the usual spines. They are flattened with the apex curved and directed distalwards. Unlike the "normal" spines that are black, they are brownish yellow. A similar row occurs in A. forcipula but not in A. marizae. Thus it cannot be regarded as a generic character of Schizocordulia. This row of modified tibiae spines has not been described by GeIJKes (1970) 
on the holotype of S. rustica. On the other hand this author describes at the fore tibia of the holotype a keel that extends to nearly one third of the tibia length whereas in the Paraná specimens it extends only to one fifth of this length. It is possible that GeIjKes (1970) regarded this row of modified spines as being the keel since in the Paraná specimens it occupies the distal third of the tibiae as described by GeIJKes (1970) for the keel. In $100 \%$ of the specimens from Paraná there are two cubitoanal crossveins in the hind wings as in A. forcipula, and auripennis whereas GEIJKES (1970), in his redescription of the holotype, mentions only one. In the key however, this author mentions two cubito-anal crossveins in hindwing as we found. In spite of the fact that the characters of the Paraná material correspond fairly well with those of the holotype there is a remote possibility that a topotype from Bahia might have the penis or the anal appendages different from the ones now described for the Paraná species in which case the latter would be a new species. As to the geographic difference it is known that most neotropical cordulids have large distribution areas For instance Aeschnosoma forcipula occurs throughout the Amazonian region including Peru and also within the Atlantic Forest of Espirito Santo (SANTOS 1981). Indeed Martin (1906) and Cowley (1934) mention the existence of a $2^{\text {nd }}$ specimen of $S$. rustica in Selys's collection from Surinam that was not found by GeIJKEs (1970). Thus, the finding of S. rustica in Bahia and Paraná is quite possible and the evidences that the Paraná specimens are really $S$. rustica are very strong.

\section{Ecological and behavioral remarks}

The specimens of $S$. rustica were collected at an old coastal road that connects the village of Pontal Sul to the city of Paranaguá in Paraná. With an altitude of $5 \mathrm{~m}$ the road crosses a "restinga" forest characterized by the presence of trees with no more than $8 \mathrm{~m}$, a sandy soil, many bromeliads, pools and marshy areas, potentially breeding places for $S$. rustica. According Prof. Mielke who visited the area many times, in the late mornings from November to February the species was very abundant flying over the sunny road. The information written in the envelopes indicate that on January 15, 2000 between 10 and $12 \mathrm{pm}$ he was able to collect 10 males and one female of $S$. rustica. A similar and unusual abundance of cordulid specimens was also observed along a road within the Cerrado near Brasilia when 11 specimens of Navicordulia were collected by N.D. Santos and H. Mesquita between 16-18:30 pm. Around 6 AM, in the Emas National Park they collected 27 specimens of Navicordulia and wrote in the envelopes: "A great number of Corduliidae were observed feeding on small insects (MACHADO \& Costa 1995). This indicates that in some species of Navicordulia aggregation for foraging occur very early in the morning and late in the afternoon. This explains the high number of specimens that can be collected at these moments. The same phenomenon seems to occur with $S$. rustica with the difference that the foraging flight is around noon and the specimens most probably live in the "restinga" forest nearby. Thus it is becoming more and more clear that the always mentioned fact that the neotropical Corduliidae are rare in the collections and in the field is not valid for the species that have foraging flight in groups as now described. By the same reason it seems that the species of Aeschnosoma don't have such a behavior because the higher number of specimens collected in a day as recorded in the literature was three for A. forcipula and A. marisae Santos, 1981. Corrorborating this view, out of the 72 specimens of Corduliidae collected by Santos near Brasilia the great majority was Navicordulia and only two, Aeschnosoma marisae (MACHADO \& COSTA 1995). This fact indicates that Schizocordulia differs from Aeschnosoma not only by its morphology but also by its foraging behavior.

\section{ACKNOWLEDGEMENTS}

I am indebted to my dear friend Prof. O.H.H. Mielke for sending me this rich and valuable Cordulid material from Paraná. I am also indebted to Myrian Morato Duarte for the drawings illustrating this paper.

\section{REFERENCES}

Cowley, J. 1934. Notes on Odonata (Corduliidae) of the neotropical region. Stylops, London, 3 (4): 91-95.

GeIJKes, D.C. 1970. Generic characters of the South American Corduliidae, with descriptions of the species found in the Guianas. Studies on the Fauna Suriname and other Guyanas, The Hague, 12 (44): 1-42.

Machado, A.B.M. \& J.M. Costa. Navicordulia gen. n., A new genus of neotropical Corduliinae, with descriptions of seven new species (Anisoptera-Corduliidae). Odonatologica, Bilthoven, 24 (2): 187-218.

Martin, R. 1906. Collections Zoologiques du Baron Edmo de Selys-Longchamp. Catalogue systématique et descriptif,Cordulines, Bruxelles, 17: 1-92.

SANTos, N.D. 1981. A new species of Aeschnosoma Selys, 1871 from Brazil with new distributional records and notes on A.forcipula Selys, 1871 (Anisoptera- Corduliidae). Odonatologica, Bilthoven, 10 (1): 43-47.

Selys-Longchamps, E. De. 1871. Synopsis des Cordulines. Bulletin de l' Académie r. de Belgique, Bruxelles, 31: 239-316, 519565 .

Received in 15.IV.2004; accepted in 24.VIII.2005. 